\title{
The Urgency of Reporting the Will as a Source of Issuing a Letter of Will on the List of the Will Center
}

\author{
Dwi Rimadona \\ Educational Science \\ Lampung University \\ Lampung, Indonesia \\ ryzalperdana2009@gmail.com
}

\author{
Aprilianti \\ Physics Department \\ Sebelas Maret University \\ Surakarta, Indonesia \\ trioyudas88@gmail.com
}

\begin{abstract}
Every human being will experience the event of death and lead to the problematics of inheritance. The making of a will is done so that later the estate left behind can be used based on the needs of the heirs. Indonesian civil law does not specify whether a Will must be made in the form of a deed under hand or an authentic deed. Although the Will is made underhand, it still asks for permission from the Notary who keeps, makes the deed of custody, and registers the Will to the Central Register of the Directorate General of Public Law Administration of the Ministry of Law and Human Rights (Director General AHU-Kemenkumham). This is following Law Number 30 of 2004 as amended by Law Number 2 of 2014 on the Notary Office (UUJN) and Regulation of the Minister of Law and Human Rights of the Republic of Indonesia Number 60 of 2016 on Procedures for Reporting Wills and Application for Issuance of Letters Electronic Will Statement (Permenkumham No.60/ 2016), which stipulates that Notaries are obliged to report/ register wills and heirs to the Register of Wills Center of the Director-General of AHU-Kemenkumham. The purpose of the research is to inventory the policies and regulations that are the legal basis for reporting wills as a source for issuing Will Certificates. This study uses normative law and legislative approaches by reviewing UUJN and Permenkumham No.60/2016. Data collection will be done through interviews and focus group discussions with Notaries, the Director-General of AHU-Kemenkumham of Lampung Province, Notary Regional Board of Lampung Province, Notary Supervisors, and the public so that they get answers to the main problems. Data analysis is done by organizing the data, breaking it into units, synthesizing it, arranging it into patterns, choosing which ones are important and to be studied, and drawing conclusions that can be told to others. The type of data analysis used in this study is a qualitative data analysis, whose data analysis is taken from written legal sources with various data collection techniques. The urgency of the research is to develop legal instruments and optimize the role of Notaries in administrative disciplines,
\end{abstract}

especially in the Reporting of Wills as a source of issuance of Will Certificates.

Keywords - Reporting, Will Deed, Will Certificate.

\section{INTRODUCTION}

In general, the property of someone who has died will fall to his family and closest people, this is regulated in inheritance law. Not infrequently inheritance is a source of problems that arise in the heirs when the heirs have died, the problem is usually in the form of conflicts over the inheritance of inheritance in the distribution of the heirs. The heir needs to make a will before he dies so that the inheritance of the heir can be maintained and avoid seizure of property by the heirs. The will contains the mandate and a firm statement from the testator if he has died regarding the assets he has, to whom the assets will be given, including funeral arrangements, discussions regarding the distribution of assets, and appointing other parties to discuss his will. This is important for the bereaved family and loved ones to know. A will can only be stated to be either a written deed itself or a lograpist, either by a general deed or a secret or closed deed. Although a will must be made in the form of a deed, civil law does not specify whether it must be made in the form of an underhand deed (made and signed by the testator himself) or an authentic deed (made by and before a notary). In practice, a will is usually made in the form of an authentic deed. This is important for proof because an authentic deed has perfect evidence strength. Even though the will is made under the hand, it still asks for permission from a notary who will keep, make a deed of deposit, and register a will with the Central Register of Wills and the Heritage Center of the Directorate General of General Legal Administration of the Ministry of Law and Human Rights of the Republic of Indonesia (hereinafter referred to as the Directorate General of Human Rights). AHU-Kemenkumham). 
This is following Law Number 30 of 2004 as amended by Law Number 2 of 2014 concerning Notary Positions (UUJN) and Regulation of the Minister of Law and Human Rights of the Republic of Indonesia Number 60 of 2016 concerning Procedures for Reporting Wills and Requests for Issuance Electronic Will Certificate [1].

After the beneficiary dies, a closed or secret will must be submitted to the Balai Harta Peninggalan which in its territory the inheritance has fallen, the Balai must open the letter and make a verbal process of receiving and opening a will regardless of the circumstances under which the will is in place, to return it to the Notary. If you look at the provisions of the relevant laws, especially UUJN Article 16 paragraph 1 letter $\mathrm{h}$ and I, a Notary must make a List of Deeds relating to a will and report it every month no later than 5 (five) days in the first week to the Central Register of Wills and the Heritage Center. The Director-General of AHU-Kemenkumham, although there is no obligation to make a report to the Balai Harta Peninggalan the Balai Harta Peninggalan receives a lot of information from the Notary of a copy of the said general will report. Issuance of Certificate of Inheritance Rights and Certificate of Will as evidence containing the subject of rights or heirs who are entitled to inheritance from the Heirs cannot be separated. Regarding inheritance, the two letters often have their problems.

Based on the identification of the problems above, this study will discuss the factors that are the reasons for not being able to issue a Will Certificate by the Central List of Wills and their legal consequences.

\section{THEORETICAL BASIS}

\section{A. Notary Public}

Based on Article 1 UUJN, a Notary is a public official who is authorized to make an authentic deed and has other authorities as referred to in this law or based on other laws. People often refer to a letter issued by a notary as a deed, even though the letter issued by a notary is not a deed, but still only a letter that has no legal force. Notaries usually issue letters for administrative purposes and correspondence, such as cover notes, reports regarding wills to the Ministry of Law and Human Rights, and so on. Article 1868 of the Civil Code (KUHPdt) states that an authentic deed is a deed made in the form determined by law by or before a public official authorized for that at the place where the deed was made. One of the authentic deeds made before a Notary as a public official is a Will Deed.

\section{B. Will Deed}

Based on Article 874 of the Criminal Code, the inheritance of a person who dies is the property of the heir according to the law, as long as the heir does not stipulate otherwise by a will. This article can be interpreted that there is a possibility that an inheritance will be inherited based on a will and based on the law. Article 875 of the Criminal Code, a will is a deed that contains a person's statement about what he wants will happen after death. A will is a deed, a statement made as evidence with the intervention of an official [2].

The will itself consists of various types and forms. Judging from its contents, wills are divided into 2 (two) types, namely wills containing erfstelling (wills for the appointment of heirs) and wills containing grants (will grants) which can be called legaat. In terms of form, wills are divided into wills that must be written themselves (Olographis Testament), general wills (Openbaar Testament), secret wills or closed testaments (Geheim), making testaments abroad and making testaments in extraordinary circumstances [3]. Each type and form of the will above can be made either in an authentic deed before an official or a private deed. In this case, the official authorized to make a will is a notary. Article 931 of the KHPdt states that a will can only be made with a holographic deed (written by one's hand), or a general deed, or a secret deed (a closed deed).

\section{Will Reporting}

The notary has the duty and obligation to keep, send, and report the list of wills he has made to the Heritage Center and the Central List of Wills. The Balai Harta Peninggalan has the task of carrying out the completion of the opening and registration of a will following the laws and regulations. Along with the development and changes in the legal system in Indonesia, in 1987 all representatives of Balai Harta Peninggalan throughout Indonesia were abolished according to the Decree of the Minister of Justice of the Republic of Indonesia Number M.06-PR.07.01 of 1987. Currently, there are only 5 (five) Balai Harta Peninggalan in Indonesia, namely, in Jakarta, Semarang, Surabaya, Medan, and Makassar and each covers the working areas of level I and level II regions. Jakarta Heritage Center has 8 (eight) working areas covering the Special Capital Region (DKI) Jakarta, West Java, Banten, Lampung, South Sumatra, Bangka Belitung, Jambi and West Kalimantan. Following the Regulation of the Minister of Law and Human Rights of the Republic of Indonesia Number M-01.PR.07.10 of 2005 concerning the Organization and Work Procedure of the Regional Office of the Ministry of Law and Human Rights of the Republic of Indonesia [4], Balai Harta Peninggalan is a Technical Implementation Unit located within the Ministry of Law and Human Rights Regional Office under the Legal and Human Rights Service Division, but technically it is directly responsible to the DirectorGeneral of AHU through the Civil Directorate [5]. To realize the efficiency of the registration system, on March 28, 2014, the Ministry of Law and Human Rights issued an online will registration system by a Notary. The Minister of Law and Human Rights has also issued Regulation No. 60/2016 as the basis for online will reporting. 
In practice, there are still many Notaries who have not registered and are often late in registering a will online with the Center for Will Register of the DirectorGeneral of AHU-Kemenkumham. UUJN does not mention the fines for each delay, both delays regarding the list of wills to the Ministry of Law and Human Rights and delays in sending repertory records. Article 10 paragraph 1 Permenkumham no. 60/2016, states that if the Notary does not report the Register of Deeds or List of Nil to the Central List of Wills, and is late in submitting the List of Deeds or List of Nil within a period of no later than 5 (five) days in the first week of each following month, all legal consequences arising in connection with the Willing Deed Report is the responsibility of the Notary concerned. Furthermore, a Notary who does not report the Register of Deeds or List of Zero will be subject to sanctions following the provisions of the legislation. Article 943 of the KUHPdt stipulates that every Notary who keeps wills among the originals, in whatever form must, after the testator dies, notify all interested parties. It can be concluded that the Notary has an important function in making a will from the beginning to the end so that the will has binding legal force.

\section{Certificate of Will}

In Article 1 paragraph 6 of the Minister of Law and Human Rights No. 60/2016 it is written that a Will Certificate is a letter that explains whether or not a Will is registered or not registered before a Notary that has been reported to the Central List of Wills. A will can be in the form of an unregistered statement or a registered testament deed in the name of the person whose will information is being applied for. Every application for a Will Certificate must be examined by the Central List of Wills. If the results of the examination of the Will Certificate are declared complete, the Director of Civil Affairs shall issue the Will Certificate.

In Article 17 Permenkum No. 60/2016 written Statement of Will can be in the form of information as follows :

- Unregistered testament deed in the name of the person whose testament is being applied for;

- Registered testament deed in the name of the person whose testament is being applied for. The inclusion of the will mentioned in the Will Certificate is the listing of all wills that are reported and registered in the Central List of Wills database.

In carrying out his position, the obligations of a Notary following Article 16 paragraph 1 of the UUJN relating to a Will Deed, namely:

- Make a list of deeds relating to wills according to the order in which the deeds are made every month.

- Send a list of deeds or a list of nil deeds relating to wills to the center of the will register at the ministry that administers government affairs in the field of law within 5 (five) days in the first week of each following month.

- Record in the repertoire the date of sending the will at the end of each month. This is important to guarantee the protection of the heirs' interests, which at any time can be traced or traced to the truth of a will that has been made before a notary.

\section{E. List of Will Centers}

Article 16 paragraph (1) letter i of the UUJN gives instructions to Notaries to make a monthly report to the Central List of Wills on the wills made before them during the current month and the report must have been sent to their address no later than the 5th day of the month. next. This means that if on behalf of a deceased person to check the existence of his will immediately after his death, the appropriate time should be awaited (at least after 3 (three) months since the death of the deceased) before the official letter is sent formally to the Central Register. Wills because it is possible that when questions for that are received by the Central List of Wills, reports from Notaries who must enter the Central List of Wills (which will be used as the basis for answering these questions) have not been received at all by the Central List of Wills, as a result, it is possible that the answers will be given to the interested party may be in the form of a letter stating that the deceased concerned has not left a will (nil), and this will reduce the level of legal certainty to be achieved in the settlement of the relevant model.

If it is certain which will is the last will to be carried out, that is, after obtaining a written answer from the head of the Central List of Wills section, then further investigation is carried out as to what is the final will of the testator that must be carried out on his inheritance. There are times when the official answer from the Head of the Central List of Wills is the answer "nil", meaning that it is stated that the deceased did not make a will during his lifetime, so it is clear that his inheritance can be settled ab intestato [6].

In practice, making a will is simply done using a deed entitled Will, or before independence, it is also called Will or Last-Will or Testament. Following the directives of Article 875 of the Criminal Code, which is the (final) will of the testator about what he wants will happen to the property he left behind, the contents of the will always begin with the sentence "I revoke and first delete all wills and such letters that I do before." This sentence is always included as an introductory sentence when writing the contents of the testament deed, namely to convince the reader that this is the last wish of the signatory in the letter to arrive in the letter until the date of issuance of the letter. Permenkumham No. 60/2016 explains that the List of Will Centers is the List of Will Centers of the Directorate General of AHUKemenkumham. 


\section{RESEARCH METHODS}

\section{A. Research Type}

This research is normative legal research. Normative legal research (juridical-normative), which includes research on legal principles, legal systems, legal comparisons, which are obtained from library research to obtain secondary data. Normative legal research is library research that uses secondary data sources or library data [7]. This research uses normative law research and a statute approach by examining UUJN and Permenkumham No. 60/2016. Normative legal research focuses on an inventory of positive law, legal principles and doctrines, legal findings in cases in concreto, legal systems, synchronization levels, legal comparisons, and legal history.

\section{B. Data Collection Technique}

Analysis of legal materials is carried out in a prescriptive-analytic manner, namely examining legal concepts, legal principles, legal norms, and legal systems related to Reporting Wills to the Center for Will Lists at the Director-General of AHUKemenkumham. Data analysis is done by organizing the data, breaking it down into units, synthesizing, compiling into patterns, choosing which ones are important and will be studied, and making conclusions that can be told to others [8].

The type of data analysis used in this study is in the form of qualitative data analysis, whose data analysis is taken from written legal sources with various data collection techniques. The analysis was carried out based on the data obtained, then developed into a hypothesis.

In library research, the data sought is secondary data that is relevant to the problem under study. Secondary data, namely data obtained from library materials, are ready to be made and can be used immediately. 23 The binding angle, which is used is secondary data in the form of legal materials:

\section{1) Primary Legal Materials have binding power}

- Civil Code

- Permenkumham No. M-01.PR.07.10 of 2005.

- Regulation of the Minister of Law and Human Rights of the Republic of Indonesia Number 27 of 2013 concerning Amendments to the Regulation of the Minister of Law and Human Rights Number M.02-Ht.05.10 of 2005 concerning Applications for Permits for the Implementation of the Sale of Assets whose owners are declared absent and inheritances Those who are not managed under the management and supervision of the Heritage Center [9].

- Permenkumham No. 60/2016.
- Law Number 2 of 2014 concerning Amendments to Law Number 30 of 2004 concerning Notary Positions (UUJN)

2) Secondary Legal Materials provide explanations or further information on primary legal materials and their contents are not binding

- Books.

- Journal.

- Research results.

- Other scientific works are relevant to this paper.

- Interviews with various sources.

3) Tertiary Law Material

Materials that provide instructions or explanations for primary and secondary legal materials, such as Big Indonesian Dictionary.

\section{Data Analysis}

Data that has been collected both from library research and field research is then collected, selected, clarified, and identified for later analysis quantitatively, which is a data analysis method carried out by grouping and selecting data obtained from field research according to quality and truth, then associated with the theories obtained from the study of literature to obtain answers to the problems posed. Then the results are presented qualitatively.

\section{RESULTS AND DISCUSSION}

\section{A. Registration and Reporting of Wills}

Article 1 Permenkumham No. 60/2016 explains that Will Reporting is the submission of a monthly Notary report in the form of a List of Deeds or a List of Nil or will reporting. The Procedure for Reporting Wills as regulated in Permenkumham No. 60/2016, as follows :

1) Section 2

- Notaries are obligated to make a Register of Deeds or a List of Nil relating to a Will.

- List of Deeds or List of Nil as referred to in paragraph (1) must be reported to the Central List of Wills.

\section{2) Article 3}

- Reporting on the Register of Deeds or List of Nil is done electronically through the official website of the Directorate General of AHUKemenkumham.

- The report on the Register of Deeds or List of Zero as referred to in paragraph (1) shall be submitted within a period of no later than 5 (five) days in the first week of each following month.

3) Article 4

Reporting the List of Deeds includes : 
- General will;

- Aan holographic will;

- Will Grants;

- Secret or secret will; or

- Revocation of Will.

If the Notary does not register and report the will to the Central Register of Wills, the strength of the deed, especially outwardly and materially, can be doubted, even though the external evidence itself is the signature of the official, namely the Notary, is the authenticity of the deed itself and for material evidence, namely as long as whatever is contained. The deed has absolute material proof power for the parties. If there is a third party who denies the evidence, of course, it will be left to the judge's consideration. The will of the Ministry of Law and Human Rights and the Certificate of Inheritance issued by the Balai Harta Peninggalan/Notary/Lurah besides all legal consequences that arise in the future are the responsibility of the Notary concerned and the Notary will of course be subject to sanctions following the provisions of the applicable laws.

A will deed made by a notary but not registered remains valid as authentic and is not null and void because the main element of an authentic deed is a deed made by and or before a public official determined by law. It also does not apply as a private deed because Article 16 Paragraph (10) of the UUJN clearly states that the provision of proof as an underhand deed mentioned in the previous paragraph does not apply to the making of a will. Not being registered with a will also do not invalidate the right of the person concerned to receive his or her rights, although administrative sanctions such as reimbursement of costs, compensation, interest may be imposed on a Notary. So as long as the parties or heirs still respect the will, the will can still be enforced. So, the wills made by the parties or appearers will remain binding, because there are no subjective and objective conditions that are violated. On the other hand, the responsibility of the Notary in registering and reporting the will to the Central List of Wills does not have executive power. This is because registering and reporting a will is an obligation that must be carried out by a notary but there are no legal implications for the will itself if it is not implemented. Legal implications will occur if there is a lawsuit by a party who feels that his name is not written in the will.

Legal Basis for Reporting Wills, namely:

- Article 16 letters h, I, and j UUJN

- Articles 2 and 3 Chapter II Permenkumham No. $60 / 2016$, stipulates that a Notary is obliged to make a Register of Deeds or a List of Nil relating to a will and report it electronically through the official website of the Directorate
General of AHU-Kemenkumham which is submitted within a period of no later than 5 (five) days in the first week of each following month.

A will is made according to a person's last wish or wish before the person dies, and is made before a notary. Since 2015, will data reported online has been directly updated to https://beta-ahuonline.ahu.go.id, the official website of the Directorate General of AHUKemenkumham.

Procedure for Reporting Wills, as follows:

- Reporting Wills is carried out by a Notary through the official website of the Directorate General of AHU: www.ahu.go.id (select the "Wasiat" menu).

- Reporting time is opened 24 (twenty-four) hours from the 01 st to the 05 th of each month.

- Things that must be reported by a Notary.

List of Deeds is a Notary's report on the deed he made to the Will according to the order in which the deed was made each month which includes the making of the deed:

- General Will

- Holographic Will

- Will Grant

- Secret or secret will

- Revocation of Will

Note: Every report on the List of Deeds is subject to a non-tax state revenue rate (PNBP) Rp. 100.000,-/perdeed

Nil List is a report in which there is no Will deed made before a Notary, every Nil List report is not subject to PNBP/Rp.0,-).

Following Article 8 of the Minister of Law and Human Rights No. 60/2016, things that the Notary must pay attention to after the testament report has been successfully carried out, the Notary is obliged to keep:

- Evidence of electronic reporting on the Register of Deeds or the Zero List

- Proof of PNBP payment (if the report contains a List of Deeds)

- Submit proof of electronic reporting of the Register of Deeds or List of Zero to the local Notary Regional Supervisory Council every month.

The impact of not doing or being late in reporting wills, namely:

- All legal consequences that arise in the future are fully the responsibility of the Notary. 
- Notaries will be subject to sanctions following statutory provisions.

- Being Inaccurate:

a) Certificate of Will issued by the Ministry of Law and Human Rights Center's List of Wills.

b) Certificate of Inheritance Rights issued by the Heritage Hall/Notary/Lurah

The relevance of Will Reporting (Monthly) with the issuance of a Will Certificate is that the monthly will report is a source of information in providing information or information about the Registered or Unregistered Will in the Ministry of Law and Human Rights Center's List of Wills so that the Will Certificate becomes the basis for issuance.

If the Notary does not register the will, is late in registering the will, the registered or reported will do not arrive, the issued Will Certificate is not registered and becomes a legal problem because the inherited property has already been divided or has been sold, and so on.

\section{B. Certificate of Will}

A Certificate of Inheritance is useful as a basis or basis for making a Certificate of Inheritance (Certificate of Inheritance Rights) by a Notary or Heritage Center. Following Article 1 point 6 of the Minister of Law and Human Rights No. 60/2016 that a Will Certificate is a letter that explains whether or not a Will is registered or unregistered before a Notary that has been reported to the Central Register of Wills.

Article 17 Permenkumham No. 60/2016 states that a Will Certificate can be in the form of the following information :

- Unregistered testament deed in the name of the person whose testament is being applied for;

- Registered testament deed in the name of the person whose testament is being applied for. The inclusion of a will that is mentioned in a testamentary certificate is to include all wills that are reported and registered in the database of the Central List of Wills.

Manually requesting a Will Certificate is as follows:

- Application for Issuance of a Will is submitted directly to the Directorate General of AHU

- The required documents for Issuance of a Will are attached to the Application for Issuance of a Will.

- If the person for whom a testament is being applied for dies before the reporting time (the 1st to the 5th of each following month), the Applicant has not been able to apply for a
Certificate of Will within a maximum period of 60 (sixty) days from the date of death of the person for whom a testament is being requested.

- Document inspection of the Application for Issuance of a Will is carried out by the Central List of Wills Section manually.

- The period of examination of the application for Issuance of a Will is a maximum of 14 (fourteen) days from the date the application is received by the Sub-Directorate of Inheritance and State Curator of the Directorate General of AHU-Kemenkumham.

- SKW products/outputs are collected at the service counter of the Directorate General of AHU-Kemenkumham or sent by post to the address of the applicant.

The application for an electronic Will Certificate is as follows:

- Application for Issuance of a Will is uploaded on the official page of the Directorate General of AHU-Kemenkumham.

- The required documents for the Application for Issuance of a Will are uploaded on the official website of the Directorate General of AHUKemenkumham.

- If the person for whom a testament is being applied for dies before the reporting time (the 1 st to the 5 th of the following month), the applicant has not been able to apply for a Certificate of Will within 30 (thirty) days as of the date of death of the person for whom a testament is being requested.

- Examination of the document of the Application for Issuance of a Certificate of Will is carried out by the Central Register of Wills section electronically.

- The period of examination of the application for the issuance of a will is no later than 3 (three) days from the date the application is received.

- The product/output of the Certificate of Will is printed independently by the Applicant by downloading (download).

Procedure for the application for issuance of a Will Certificate in electronic form:

- The applicant (individual or notary or agency ex. Balai Harta Peninggalan) applies by filling in the form on the www.ahu.go.id page (select the "Wasiat" menu

- Applicant uploads the required documents: 
a) Original/photocopy of the original copy of the Death Certificate issued by the Office of Population and Civil Registry or death certificate, issued by the Village Head/Lurah/Camat on behalf of the person whose testament is being applied for. b) Determination Letter/Statement of Change of Name from the District Court or the competent authority on behalf of the person whose will information is being requested.

c) Proof of payment of PNBP Certificate of Will in the name of the person whose testament is being applied for.

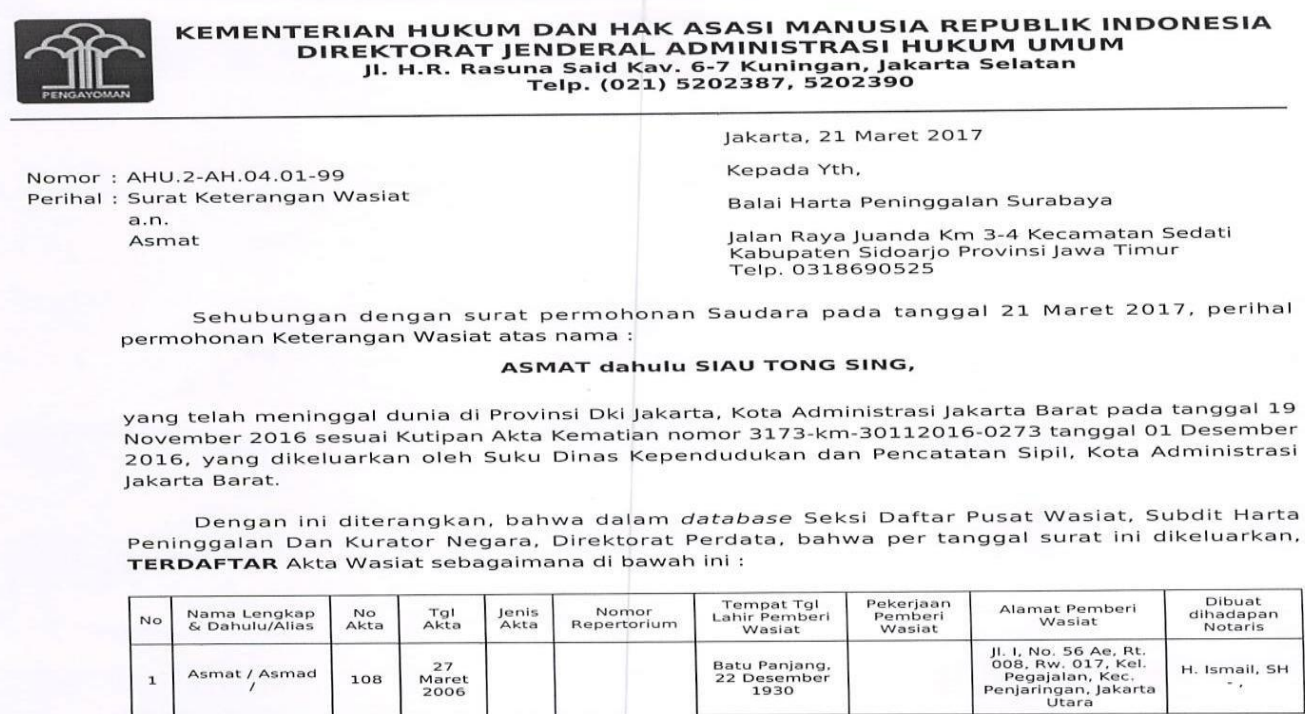

Akta tersebut adalah akta wasiat yang terdaftar yang kami terima berdasarkan laporan bulanan Notaris sampai formalitas, maka akta wasiat tersebut harus didaftarkan pada Kantor Balai Harta Peninggalan d wilayah kerja saudara, mengingat akta wasiat akan berakibat hukum setelah pewasiat meningga dunia.

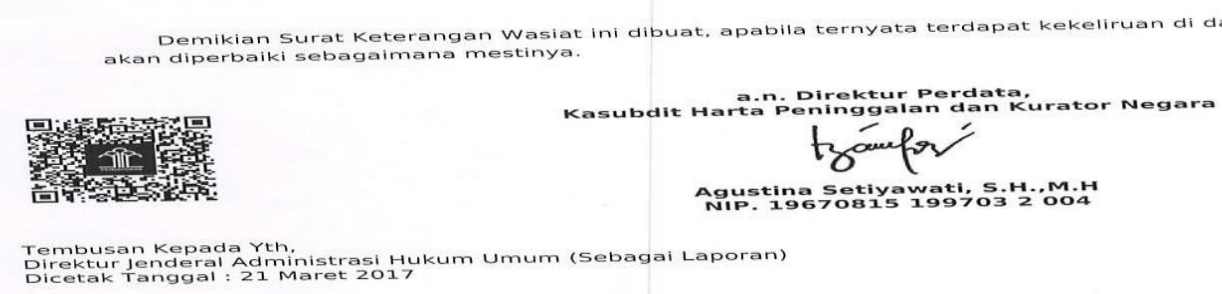

Fig. 1. Example of a "Registered" Electronic Will Certificate (new version online - there is a barcode)

\section{Factors Cannot Issuance a Will Certificate by the Central List of Wills}

In practice, there are still many Notaries who have not registered and are often late in registering a will online to the Center for the Will Register of the Director-General of AHUKemenkumham. UUJN does not mention the fines for each delay, both delays regarding the list of wills to the Ministry of Law and Human Rights and delays in sending repertory records. Article 10 paragraph 1 Permenkumham no. 60/2016, states that if a Notary does not report the Register of Deeds or List of Nil to the Central List of Wills, or is late in submitting the List of Deeds or List of Nil within a period of no later than 5 (five) days in the first week of each following month, all legal consequences arising in connection with Will Reporting is the responsibility of the Notary concerned. Furthermore, a Notary who does not report the Register of Deeds or List of Zero will be subject to sanctions following the provisions of the legislation.

Notary/PPAT Ilanur, S.H., M.Kn. said that he had never personally made a will, so far he had only reported wills at the beginning of every month which was carried out no later than every 5 th. Sometimes the Notary was also late or did not 
report the will because he forgot the report must be done online, plus never get a will order. If a Notary has an order for a will that is not reported, the effect can be criminal and civil, if the civil sanctions can be seen in the UUJN regarding the functions and powers of a notary, if he neglects to carry out his position, the notary can be subject to sanctions regarding losses.

Notary/PPAT Riadh Indrawan, S.H., M.H., M.Kn. said that usually, the obstacles that occur are at the time of making the will. In the case of a will report, it usually depends on whether the notary wants to be active or not, whether in the current month the notary makes a will or not, and then it is reported to the Director-General of AHU online every before the 5th. making a will, after a notary makes a will according to the request of the testator, then the testator dies, then the family (heirs) of the testator do not necessarily know that the testator made a will either in private (made by himself) then entrusted to a notary) or openly (made notarial in front of a notary and 2 (two) witnesses), then when the testator dies, the family of the testator does not provide information to the notary and no one in the family knows that the testator has made a testament deed or minutes submit a will to a notary. The notary makes a certificate of inheritance and coordinates with the Ministry of Law and Human Rights, but if the natives have nothing to do with the notary because the majority of indigenous people make their wills in front of the lurah and camat.

A will that is not registered in the Central Register of Wills, the legal status of the deed remains as an authentic deed where this online registration is only a form of administrative order and can be used as a reason for the parties concerned to try to cancel the will because the obligations regarding the registration have been regulated in Legislation so that if these provisions are violated the legal consequences are that the will can be used as the basis for a lawsuit by the heirs. If a notary registers more than 5 (five) days in the first week of each subsequent month as referred to in Article 16 paragraph (1) letter $\mathrm{j}$ of the UUJN, access to the registration will be locked. So that the notary can no longer report wills online in that month so that the monthly editorial reports submitted to the Central List of Wills are nil and the Will Certificate cannot be issued, whereas if the notary concerned makes a will report, then the editorial report is submitted to the Register The Will Center is registered. As referred to in Article 91A, the procedure for imposing sanctions for notaries is regulated in a Ministerial Regulation which is still in the drafting stage. It is hoped that the regulation will contain the legal consequences of wills that are not registered online with the Ministry of Law and Human Rights.

With strict rules regarding this matter, it is also hoped that notaries will be more orderly in terms of sending reports as confirmed in Article 16 paragraph (1) letter $\mathrm{j}$ of the UUJN. In the Ministerial Regulation which is still in the drafting stage, it is also expected to regulate the sanctions and procedures for imposing them. It is hoped that the sanctions will be fair to the parties and applied indiscriminately to all notaries so that they have a deterrent effect and the notaries will become more orderly.

\section{Legal Consequences of Negligence of a Notary Who Don't Submit or Late Submitting a List of Wills After the Deadline}

Santosa, $\mathrm{SH}, \mathrm{MH}$, as the Legislative Designer at the Directorate General of AHU of the Ministry of Law and Human Rights, Bandar Lampung regional office, said that every maximum of 5 notaries must report the will to the Central List of Wills following Permenkumham No. 60/2016 which will soon be changed from the office Center, procedures for registration and reporting of wills can also be seen in Permenkumham No. 60/2016. If the Notary does not report the will past the 5th, then the Notary can report it in the following month, including wills that are abroad also must be reported. Furthermore, wills that have been submitted before the enactment of Permenkumham No. 60/2016 can be processed manually and must be completed no later than 6 (six) months from the promulgation of this Ministerial Regulation. If there is negligence made by the Notary in terms of registration or reporting of wills, then the full risk responsibility must be accepted by the Notary, be it criminal or civil sanctions as a legal consequence. Article 10 Permenkumham No. 60/2016, that all legal consequences arising to Will Reporting are the responsibility of the Notary concerned. Notaries who do not report the List of Deeds or List of Zero are subject to sanctions following the provisions of the legislation.

Includes authority in the context of carrying out duties, and granting authority and distribution of the main authority stipulated in the laws and regulations. If it is associated with the theory of responsibility, the responsibility carried out by a Notary is the result of the implementation of his duties and positions. Thus, the responsibility used in UUJN is based on error. Gunawan Ali, SH, as the Head of the Program and Reporting Sub Division of the Kemenkumham Regional Office for the Lampung region, explained that the responsibility of a Notary who does not register and report a will following UUJN is the responsibility of a position where a Notary does not register and report a will is a violation of the obligations stated in the Indonesian Notary Code of Ethics that the Notary is obligated to the attitudes, behavior, actions, or actions that must or must be carried out and carry out the position of a Notary to maintain the image and authority of the notary institution and the nobility and dignity of the position of a Notary. Regarding the registration of a will which is the obligation of a Notary and anything that is violated will have a loss. For the community, especially the parties, there is no legal certainty. For Notaries, legal problems will arise not directly, but in the future. Notaries who neglect their positions, intentionally or unintentionally, will be subject to sanctions. UUJN states that the lightest sanction is a written warning, the second sanction is temporary dismissal and the third, sanction is respectful dismissal. The final sanction is dishonorable dismissal. The sanction is internal, namely the imposition of administrative sanctions as an administrative responsibility by a Notary. The sanction is imposed by the Notary Supervisory Council as a means, effort, and tool to enforce the obedience and discipline of a Notary in carrying out the position of a Notary. The report must be submitted in writing in Indonesian and accompanied by reliable evidence. The report is submitted to the Regional Supervisory Council (hereinafter referred to as MPD) then the MPD submits it to the Regional Supervisory Council (hereinafter referred to as MPW) and will be forwarded to the Central Supervisory Council (hereinafter referred to as MPP), then the MPP forwards it to the 
competent MPD. After that, the Chairman of the Examining Council shall summon the complainant and the reported party. Summons are made by letter by the secretary no later than 5 (five) working days before the trial. If the reported party has been legally and properly summoned but is not present a second summons and a second summons will be made but still not present, then an examination is carried out and the decision is pronounced without the presence of the reported party. After being legally and properly summoned for the second time but still not present, the examination is carried out and the decision is pronounced without the presence of the reported party.

Examination by MPD is closed to the public. The inspection begins within a period of no later than 7 (seven) calendar days after the report is received. The MPD must have completed the examination and submitted the results of the examination within a period of no later than 30 (thirty) calendar days as of the receipt of the report. The cover letter for sending the inspection report sent to MPW is copied to the reporter, the reported party, the MPP, and the Regional Board of the Indonesian Notary Association. At the first meeting that is determined, the reporter and the reported party are present, then the Regional Examination Board examines by reading out the report and hearing the statements of the complainant. The complainant and the reported party can submit evidence to support the arguments put forward. The report is examined by the MPD within a period of no later than 30 (thirty) calendar days as of the receipt of the report. After that, an examination is carried out by the Regional Assembly which is closed to the public, while the decision is pronounced in a trial which is open to the public. MPW begins to examine the results of the MPD examination within a period of no later than 7 (seven) calendar days since the file is received. Decisions are pronounced within a period of no later than 30 (thirty) calendar days from the receipt of the documents.

In violation of the UUJN, there is a violation of Article 16 paragraph (1) letter $\mathrm{j}$ of the UUJN which states that in carrying out his position, the Notary is obliged to send a list of deeds as referred to as the null list about wills to the Central List of Wills at the Ministry that carries out government affairs in the legal field. within 5 (five) days in the first week of each following month. Notaries who commit violations by not registering and reporting wills to the Central List of Wills may be subject to ethical sanctions in the form of temporary dismissal and dishonorable dismissal and may also be subject to sanctions in violation of UUJN, namely respectful and dishonorable dismissal as a Notary and of course an association., in addition to verbal and written reprimand sanctions. Notaries can also be sued civilly if they neglect their obligations in registering and reporting wills by other people, especially by the giver and recipient of the will in which the responsibility of the notary is related to moral norms which are a measure for the notary to determine right or wrong and good or bad actions taken. carried out in carrying out their duties. The form of the Notary responsibility in the field of civil law sanctions in the form of compensation costs and interest as a result that the Notary will receive. This is following Article 16 paragraph 12 UUJN.

The results of the study indicate that the legal consequences of a will that are not registered by a Notary at the Center for a Will are that it can cause the deed to be degraded into a private deed. Other legal consequences are causing the inaccurate Will Certificate issued later by the
Ministry of Law and Human Rights Center's List of Wills and inaccurate Inheritance Certificate issued by the Heritage Hall or Notary or Village/Kelurahan and Camat Heads. Even notaries can be sued by parties who are harmed due to the violation of these obligations. The notary's responsibility for wills that are not reported to the Center for the List of Wills is an official responsibility because the reporting is an act of an official and is a burden of office obligations, not a person as a person. For this reason, a notary who does not carry out his obligations may be subject to criminal, civil, and administrative sanctions as stipulated in the UUJN and other laws and regulations. In addition, the action of a notary who violates the provisions of Article 16 paragraph (1) letter $\mathrm{j}$ of the UUJN is an act that violates the law in terms of contradicting the legal obligations of the perpetrator and based on this action some parties suffer losses, namely the heirs or third parties.

TABLE I. DATA OF LETTER APPLICATION FOR A LETTER OF WILL IN LAMPUNG PROVINCE IN 2021 (UNTIL OCTOBER 2021)

\begin{tabular}{|l|c|}
\hline \multicolumn{1}{|c|}{ Month } & Request \\
\hline January & 13 \\
\hline February & 12 \\
\hline March & 14 \\
\hline April & 10 \\
\hline May & 19 \\
\hline June & 11 \\
\hline July & 2 \\
\hline August & 24 \\
\hline September & 40 \\
\hline October & 13 \\
\hline November & - \\
\hline December & - \\
\hline Total & $\mathbf{1 5 8}$ \\
\hline
\end{tabular}

\section{CONCLUSION}

Will Reporting is the submission of a Notary's monthly report in the form of a List of Deeds or a List of Nil or will be reporting. If the Notary does not register and report the will to the Central List of Wills, the strength of the deed, especially externally and materially, can be doubted. If there is a third party who denies the evidence, of course, it will be left to the judge's consideration. The will of the Ministry of Law and Human Rights and the Certificate of Inheritance issued by the Balai Harta Peninggalan/Notary/Lurah in addition to all legal consequences that arise in the future are the responsibility of the Notary concerned and the Notary will of course be subject to sanctions following the provisions of the applicable laws and regulations. Article 10 paragraph 1 Permenkumham no. 60/2016, states that if a Notary does not report the Register of Deeds or List of Nil to the Central List of Wills, or is late in submitting the List of Deeds or List of Nil within a period of no later than 5 (five) days in the first week of each following month, all legal consequences arising in connection with Will Reporting is the responsibility of the Notary concerned. Notaries who do not report the List of Deeds or List of Zero are subject to sanctions following the provisions of the legislation

Notaries who neglect their positions, intentionally or unintentionally, will be subject to sanctions. UUJN states that the lightest sanction is a written warning, the second sanction is temporary dismissal and the third, sanction is respectful dismissal. The final sanction is dishonorable dismissal. The sanction is internal, namely the imposition of administrative sanctions as an administrative responsibility by a Notary. The 
sanction is imposed by the Notary Supervisory Council as a means, effort, and tool to enforce the obedience and discipline of a Notary in carrying out the position of a Notary. The report must be submitted in writing in Indonesian and accompanied by reliable evidence. In violation of the UUJN, there is a violation of Article 16 paragraph (1) letter $\mathrm{j}$ of the UUJN which states that in carrying out his position, the Notary is obliged to send a list of deeds as referred to as the null list about wills to the Central List of Wills at the Ministry that carries out government affairs in the legal field. within 5 (five) days in the first week of each following month. Notaries who commit violations by not registering and reporting wills to the Central List of Wills may be subject to ethical sanctions in the form of temporary dismissal and dishonorable dismissal and may also be subject to sanctions in violation of UUJN, namely respectful and dishonorable dismissal as a Notary and of course an association., in addition to verbal and written reprimand sanctions. Notaries can also be sued civilly if they neglect their obligations in registering and reporting wills by other people, especially by the giver and recipient of the will in which the responsibility of the notary is related to moral norms which are a measure for the notary to determine right or wrong and good or bad actions taken. carried out in carrying out their duties. The form of the Notary responsibility in the field of civil law sanctions in the form of compensation costs and interest as a result that the Notary will receive.

The results of the study indicate that the legal consequences of a will that are not registered by a Notary at the Center for a Will are that it can cause the deed to be degraded into a private deed. Other legal consequences are causing the inaccurate Will Certificate issued later by the Ministry of Law and Human Rights Center's List of Wills and inaccurate Inheritance Certificate issued by the Heritage Hall or Notary or Village/Kelurahan and Camat Heads. Even notaries can be sued by parties who are harmed due to the violation of these obligations. The notary's responsibility for wills that are not reported to the Center for the List of Wills is an official responsibility because the reporting is an act of an official and is a burden of office obligations, not a person as a person. For this reason, a notary who does not carry out his obligations may be subject to criminal, civil, and administrative sanctions as stipulated in the UUJN and other laws and regulations. In addition, the action of a notary who violates the provisions of Article 16 paragraph (1) letter $j$ of the UUJN is an act that violates the law in terms of contradicting the legal obligations of the perpetrator and based on this action some parties suffer losses, namely the heirs or third parties.

\section{ACKNOWLEDGMENT}

The author would like to thank Allah SWT for all His graces and gifts so that the author can complete this writing and research. The author also expresses his deepest gratitude to all parties who have helped directly or indirectly, so that this writing and research can be completed on time. This writing and research examine the urgency of Will Deed Reporting as a Source for Issuing Will Certificates on the List of Will Centers.

In the process of preparing and completing this, there are many parties involved and helping. Allow me to express my gratitude for all material and moral assistance in completing this writing and research, as follows :
- Dr. M. Fakih, S.H., M.S., as the Dean of the Faculty of Law, University of Lampung;

- Dr. Sunaryo, S.H., M.Hum., as the Head of the Civil Law Section, Faculty of Law, University of Lampung;

- Dr. Ir. Lusmeilia Afriani, D.E.A., as Chair of the University of Lampung LPPM;

- Aprilianti, S.H., M.H., as a Lecturer of the Civil Law Faculty of the University of Lampung who has become a member and assisted in the completion of this writing and research;

- Notary/PPAT Ilanur, S.H., M.Kn., as Notary/PPAT Bandar Lampung city who has taken the time and is willing to be interviewed regarding this research;

- Notary/PPAT Riadh Indrawan, S.H., M.H., M.Kn. as Notary/PPAT Bandar Lampung city who has taken the time and is willing to be interviewed regarding this research;

- Santosa, S.H., M.H., as Legislative Designer at the Director-General of AHU of the Ministry of Law and Human Rights at the Lampung regional office who has taken the time and is willing to be interviewed regarding this research;

- Gunawan Ali, S.H., as the Head of the Program and Reporting Sub Division of the Lampung Regional Office of the Ministry of Law and Human Rights, who has taken the time and is willing to be interviewed regarding this research;

- All parties who have helped the author during the process of completing this research, which without reducing respect, the author cannot mention one by one. Hopefully, everything that you have given will get a good reward from Allah SWT;

The completion of this research cannot be mentioned one by one. May God reward me for all the services and kindness that have been given to me. In the end, I realize that although the writing of this research has been prepared as well as possible, it will not rule out the possibility of errors that result in the writing of this research not being perfect, but I hope that writing this research will bring benefits to anyone who reads it and for the author in developing and practice science.

\section{REFERENCES}

[1] Peraturan Menteri Hukum Dan Hak Asasi Manusia Nomor 60 Tahun 2016 Tentang Tata Cara Pelaporan Wasiat Dan Permohonan Penerbitan Surat Keterangan Wasiat Secara Elektronik.

[2] R. I. Aprilianti. Hukum Waris Menurut Kitab Undang-Undang Hukum Perdata (Burgerlijk Wetboek). Bandar Lampung : Fakultas Hukum Universitas Lampung. 2015

[3] M. Suparman. Hukum Waris Perdata. Jakarta : Sinar Grafika. 2015

[4] Peraturan Menteri Hukum dan Hak Asasi Manusia Republik Indonesia Nomor M-01.PR.07.10 tahun 2005 tentang Organisasi dan Tata Kerja Kantor Wilayah Departemen Hukum dan Hak Asasi Manusia Republik Indonesia Nomor M-01.PR.07.10 tahun 2000.

[5] F. Levia, and E. Agustin. Jurnal Tanggung Gugat Notaris Dalam Pelaksanaan Pendaftaran Wasiat Secara Online. Surabaya: Fakultas Hukum Universitas Airlangga. 2017.

[6] S. Sofyan. Beberapa Dasar Teknik Pembuatan Akta (Khusus Warisan). Medan : Pustaka Bangsa Press. 2011.

[7] S. Soekanto, and S. Mamudji. Penelitian Hukum Normatif. Jakarta : Raja Grafindo Persada. 2009. 
[8] I. G. A.B. Wiranata. Hukum Telematika. 2017.

[9] Peraturan Menteri Hukum Dan Hak Asasi Manusia Republik Indonesia Nomor 27 Tahun 2013 Tentang Perubahan Atas Peraturan Menteri Hukum Dan Hak Asasi Manusia Nomor M.02-Ht.05.10 Tahun 2005 Tentang Permohonan Izin Pelaksanaan Penjualan Harta Kekayaan Yang Pemiliknya Dinyatakan Tidak Hadir Dan Harta Peninggalan
Yang Tidak Terurus Yang Berada Dalam Pengurusan Dan Pengawasan Balai Harta Peninggalan 